\title{
ХЕТЕРОГЕНОСТ НАУЧНИХ ПРИСТУПА У ЗБОРНИКУ ПОЕТИКА СРПСКОГ РЕАЛИЗМА
}

(Поетика српског реализма, зборник радова, ур. Душан Иванић, Драгана Вукићевић, Филолошки факултет Универзитета у Београду, Београд, 2018)

„Поетика српског реализма” је пројекат покренут од стране професора емеритуса Душана Иванића 2011. године са циљем изучавања поетике епохе реализма у српској књижевности као уопштавања и систематизације знања о овом раздобљу. Зборник радова „Поетика српског реализма“" настао је као продукт истоименог научног скупа одржаног у Београду 5. децембра 2016. године у оквиру поменутог пројекта.

О пројекту „Поетика српског реализма“ професор Иванић говори у првом по реду раду из Зборника штампаног 2018. године у Београду, што аутор користи да сумира резултате које је седмогодишње трајање пројекта донело. Иако је научни скуп децембра 2016. године био први интерни симпозијум у оквиру пројекта, већина сарадника се пре тога окупљала око извесних писаца епохе или извесних тема. Закључно са 2017. годином, према подацима професора Иванића, објављено је преко 20 зборника радова и ауторских књига, те око 300 јединица (књига, студија, чланака, критика) укупно. Главне области проучавања обухватиле су поетику жанра с разгранатим методолошко-теоријским подлогама међу којима се издваја когнитивна наратологија. Истраживачи су се бавили и поступцима приповедања попут фокализације, апелативне форме, наративног темпа и наратива. Део радова је интердисциплинаран и обухвата еротологију, етнографију и имагологију, део се бави наративним световима реалистичке прозе, а важан сегмент пројекта су и проучавања поетике појединих писаца што је допринело стварању нове конфигурације поетике српског реализма. Приликом проучавања проблемима се прилази тако да се књижевни појам везује за одређену књижевну грађу чиме се добијају различити аспекти проучавања, односно проучавања различитих поетика - имплицитне, експлицитне, историјске, дескриптивне, нормативне. Хетерогеност епохе као и хетерогеност научног приступа проблемима доводе до настанка потпуно независних и тематски различитих радова у зборнику. Ауторима то пружа могућност да према личним афинитетима 
бирају теме о којима говоре, а тако доприносе додатном осветљавању епохе српског реализма.

Снежана Милосављевић Милић се у свом раду бави типолошким статусом групних ликова и лика колектива у прозним жанровима српског реализма. Осе диференцијације до којих Сн. Милосављевић Милић долази као до адекватних параметара за типолошку класификацију групног лика су: композиција, становници фикционалних светова, критеријум актуелизације, комуникативне стратегије и рецептивне инстанце, хронотоп, облици представљања и улоге. Приступ групном лику у епохи реализма значајно је запостављен тако да теоријски модел представљен овим радом може бити подстицај за свеобухватнији и синтетичнији приступ занемареном проблему у оквиру категорије јунака, а релевантност понуђеног модела треба проверити у неким будућим истраживањима.

У раду Драгане Вукићевић анализирају се три аспекта пародије ужи реторички, књижевноисторијски и шири културолошки аспекти. У основи тумачења пародије налази се бахтиновско схватање језичког знака проширено значењима која му дају други аутори, што је ауторки дало за право да поменуто значење пародије додатно усложни - од пишчевог обрачуна са сопственом лектиром, преко обрачуна са традицијом, до обрачуна са светом.

Горан Максимовић се у раду под називом „Градови српског реализма“ бави проучавањем градова и поднебља који су обележили епоху српског реализма. Поред градова, посебно су истакнути и анализирани уметнички топоси попут градских кафана и тргова, градских периферија, јунака, прича и сл. Аутор посебно издваја два основна топоса која се налазе у значењу појма хронотопа - уметничко време и простор, јер представљају амбијент у коме је остварен приватни и јавни живот града у реалистичкој слици епохе српског реализма. Као главни закључак до ког Максимовић долази истиче се чињеница да су конкретни градови утицали на обликовање уметничких градова у епохи српског реализма, али да је повратно уметничка слика града утицала на нови доживљај реалних градова у свести читалаца.

Испитивањем утицаја Гогољевог стваралаштва на књижевност српског реализма бави се Тања Поповић у раду под називом „Шта српски реалисти дугују Гогољу“. Кључне тачке проучавања полазе од рецепције руског писца код Срба, преко разматрања превода његових дела, до најбитнијих поетичких сличности између српских реалиста и уметничког света руског класика. Ауторка приступа анализи употребе сказа, говорних фигура, стилизација, каламбура, третирања простора и времена, структуре и композиције дела. Као основни закључак компаративног проучавања писаца и њихових дела, Т. Поповић наводи да приповедни 
свет Гогоља и српских реалиста повезује оно што би Ејхенбаум назвао језичким понашањем, тј. специфична употреба усменог казивања и разговорног тона којима се стварају посебне говорне представе и емоције.

Ана Живковић у раду „Слика - прозни жанр српског реализма“, испитује „слике“ као жанровске и међужанровске категорије прозе српског реализма. Примењујући идеолошку, структуралистичку и семиотичку методу, ауторка издваја кључне композиционе поступке у слици („оквир“, путовање као мотивација, описи природе, ентеријера и екстеријера, сусрет са новим јунацима, техника сказа, дијалог, одлазак из приказаног простора) откривајући и указујући тако на процес канонизације жанра и померања слике са периферије у центар система. Поред тога, до изражаја долази и обрнути процес деканонизације слике у којем главну улогу има пародија. Као битну чињеницу издвајамо да је термин слика присутан у делима сва три књижевна рода што ауторка објашњава тиме да стратегија естетизације света делује конструисањем тачке гледишта гледаоца и обликује се захваљујући моделу метафоре позоришта.

Интертекстуални приступ проучавања поетике српског реализма заступљен је у раду Милене Станковић која се бави природом односа уметничких бајки Илије Вукићевића и жанрова усмене литературе. У раду је образложен проблем жанровске полифоније Вукићевићевих бајки настао као последица усвајања семантичко-структурних форми усмене књижевности. Кључни део проучавања односи се управо на процес трансформације усмене бајке унутар дискурса реалистичке књижевности, односно њене адаптације у новом литерарном контексту. Ауторка интертекстуалним приступом потврђује чињеницу да је уметничка бајка позног реализма сложени конгломерат хетерогених и амбивалентних усмених жанрова који се креће ка реалистичкој перцепцији света, што потврђује трима Вукићевићевим бајкама које су прешле пут од канонске до гротескно-фантастичне бајке.

Питањем фокализације у роману „Пауци“ Ива Ћипика бави се Јелена Јовановић полазећи од Женетових студија као основне апаратуре за бављење наведеним проблемом, уз консултовање и посткласичне наратолошке литературе. Ауторка наводи да је у роману доминантно заступљена спољашња фокализација као последица слике света у којој је мало простора остављено за дубљу психологизацију, за лирско, као и за стварање тзв. мапа ума. Посебан нагласак стављен је на облике приповедања којима је остварена спољашња фокализација, при чему до изражаја долази дијалошки потенцијал остварен различитим средствима за представљање говора попут директног говора, дијегетичког извештаја о обављеном говорном чину итд. Доминација спољашње фокализације са дијалогом као својим средством ретка је у српској књижевности, а J. 
Јовановић закључује да је овај особен приступ за циљ имао остављање утиска сировости, неуглачаности и изворности у књижевности на размеђи 19. и 20. века.

Интердисциплинарност у проучавању поетике српског реализма огледа се у раду Александра Костадиновића који проучава етнографске аспекте путописне прозе Симе Матавуља. Аутор посвећује пажњу модусима присуства етнографског дискурса у Матавуљевој прози условљених сложеним сплетом разноврсних фактора попут жанровских или политичких. Поред етнографије која је потпуно карактеристична за путописни жанр, Костадиновић детаљно изучава и лиминалне случајеве - peдукцију етнографског дискурса у путописној приповеци и његов развој у систематичну етнографску дескрипцију, чиме овај рад добија додатну и сложенију димензију проучавања етнографских аспеката путописне прозе једног реалистичког аутора.

Зборником радова „Поетика српског реализма“ још једном је потврђена чињеница о хетерогености истраживања која су обухваћена истоименим пројектом. Кратким приказом зборника указали смо да аутори, бавећи се наизглед потпуно разнородним књижевним темама, писцима и проблемима, једнако доприносе допуни огромног мозаика који можемо назвати поетиком српског реализма и за који можемо рећи да је спреман за будуће допуне и модификације.

Стефан М. Димитријевић ${ }^{3}$ Универзитет у Нишу Филозофски факултет Департман за србистику

\footnotetext{
${ }^{3}$ dstefan94@gmail.com
} 